\title{
Community Empowerment Through Networking Capacity Development of The Target Group of Community Entrepreneurship Education
}

\author{
Entoh Tohani \\ Non Formal Education Department \\ Yogyakarta State University \\ Yogyakarta Indonesia \\ tohani@uny.ac.id
}

\begin{abstract}
This research aims to produce development model of the networking capacity for target group of community entrepreneurship education empower community. This research done due to fact that lack of the possesion of networking capacity by the community entrepreneurship education recently. This research design is research and development approach that involved the target group of the Empowerment of Family Welfare "Mawar" located in Karangmojo, Gunung Kidul, Special Province of Yogyakarta. The data collected using methodes interview, observation, document analysis, and quantitative methode i.e questionnaire. The result research found that the model could be validated. Especially, the target group could be have positive change includes having motivation to development mutual business, awareness to enlarge business networking, and able to apply business networking capacity. Therefore, in term of producing contributive entrepreneurs to economic development, development of networking capacity need to be done directionally, masterly, and based experience.
\end{abstract}

Keywords-education, entrepreneurship, networking, empowerment

\section{INTRODUCTION}

Developement of entrepreneurial capacity, recently has been run by goverment with national entrepreneurship movement programs, private with social corporate responsibility, educational institution or community members personality who have entrepreneurship development programs. Goverment itself as one of the generators of entrepreneurship education has been developed many programs that formed of mutual business group, family empowerment groups, community entrepreneurship education, national community resilience empowerment program, productive rural program, and farmer groups. On some years, there are activities to build entrepreneurial capacity that have been done by National Educational Department, especially by Director of Training and Course Pembinaan, which is called Desa Vokasi. It is noted that management of the program on 2013 sums 90 programs that have funded, although it has decreased than 2012 that was 127 programs, and 234 programs on 2011[1].

Basicly, community entrepreneurship education gives values, attitude, knowledge and skills to create job for target group, that is community members who have not yet skills for finding jobs or they who is marginal/unlucky economically so that they could be create job themselve or work together with others. It may be on next time in running their business they will face by any limitations or obstacles which must be overcome in term of the production process, marketing, management, and so on. So, target groups have to posses capacity of the business improvement, in a way they must not focus merely to utilize resources but they must merits any opportunities that is built from social relation happen on business enviorenment. In other words, it is pressured that the target groups will be more act to develope social capital in their business. Social capital must be utilized positively because of it could be give merits to quality development of human resources, internal organization performance, production development, marketing enlargement, and innovation development [2].

There are need for developing entrepreneurial networking capacity of the target groups. It could be caused by two important things, firstly, it is a fact on teaching aspect, community entrepreneurship education recently is more oriented to developing managerial capacity on business which must be possed by them than portion of networking capacity. The 
condition marked by educational substances and learning time of the educational process incline to creation, development some skills to how manage business and/or other technical skills. It is mean that the entrepreneurship was more oriented to human capital improvement and less to build collaboration skills with others. Related to this, for instances, some finding of the initial research of entrepreneurship education which has done to marginal people show that the capacity of the target group of the community entrepreneurship education inisiated by National Education and Culture Ministry was low so that their business result is not yet give greater benefits to community [3], lack of involvement of other sides to contribute [4], and some entrepreneurship activities did oriented to entrepreneural business skills [5] [6]. Second, there are thought that community entrepreneurship education that was done by its target groups basically was effort to use resources and/or competitive advantages exist on community. Compatitive advantages will be not give merit greater if its human resource both actors and community members around have not recieve educative actions that aim to build its competencies in term of the management of services and/or goods of enterprise. In other words, these could be developed through developing competitive advantages in which it must be supported by good understanding of network structur in business world and improving contact on it [7].

Based on the above, this research done hoped to produce a model of the networking capacity development for target group of the education of community entrepreneurship in context of the enlarging of creative, innovative, and productive behaviors that is usefull to develope entrepreneurship activities well and to create optimal community development. This research must be conducted becouse of concideration that innovating of the entrepreneurship education for reducing social problem in future must be managed based on urgent information that is gained from its any development recent as inputs to reach innovation of education meaningful.

\section{LITERATURE REVIEW}

The target group of the CEE have to posses capacity as one of the dimentions of social capital [8][9], namely networking. In context of entrepreneurship, networking defined as communication skills and work together with other business actors [10]. Stated that an entreprise or entrepreneurship process should be supported by capacity to network as capability to work both internally and externally [11]. This capacity tends to acquire resources such as employees, managers and information systems, and process of business for instance marketing and business units like on activity of the chain of input business. The capacity have to owned by entrepreneurs as capital to facing business competition, and science and technology development. This caused by fact that an organization or business acitivity is not separated to other sides namely partners, customers, competitors, investors, goverment, industry influences, mass media, and associations.

Dimensions of networking could be understood by social capital theory. Networking can be devided in two aspects namely vertical and horizontal networking [12]. The former exampled by networking which happen on education institution for instance relation among teachers, or between teachers and manager staffs. The other one could be seen from activity that is created by relations between education institutions. Other dimentions of networking are that it has a level on which is consisted of broad or limited, proactiveness on which networking could be reactive or proactive, and bonding on which it could be strong or weak [13]. Also, it has to tends to reaching of simplicity on reaching or doing approachebility and availiblity[14].

Because of its urgency, creation of the capability must be done by the enterpreneurs through ways or strategies different. They includes strategy that focus on relation strengthening between themselve and their customers that focus on marketing, evaluation, buying, and activities post-selling done by consumers; strategies which is focused on management of supply chain namely business resources, planning, producing and delivery; and strategies focused on transaction process and relation of business process [15]. It also could be maintained by the actors through developing and authentic attitude, openess, ethic and keeping effective communication [16]. By building it, the target groups will be easy to understands others people that has capability or resources perhaps could be utilized for improving their business or career.

The target groups should be able to enlarge their professional networking capacity to achieve the success of bussiness [17] and opposite that if it could be not created by themselve, any possibilities of problem in running business will be found for example low benefits business and obstacle to development 
products or services produced. Or in that context, the capacity is as marketing tool of business to improve product and process of business [18]. The capacity both internally and externally may be produce resources more so that it can generates income, adn increase ssharing of knowledge and information [19], opens new business activities and be easy to acces additional business activities[20], and aslo could be more help in developing community.

Specifically, networking as a social capital dimentions has urgent role on the enterpreneurship program and business for supporting establishment of welfare. Some findings of the fact shows that networking using social media could introduce entrepreneur profile to community [21], develope learning organization, performance of organization, and sustaine competitive advantadge [22], produce social benefits such as open feeling on communicating or saying and mutual hearing of something that is likes or unlikes [23]. Besides that, it is important to develope the capacity was supported by the research that showed that adult could create, keep, reconstruct, and enrich social network [24], and mentoring is needed to build the capacity in context of the career developement [25]

\section{RESEARCH METHODS}

This research done using research and developement approach that aims to development model of the networking capacity of target group of the community enterpreneurship education in an attempt to developing community. The research done in Gunung Kidul Regency, Special Province of Yogyakarta. The target group who was developed is women who has been joined in group to Family Welfare Empowerment and have mutual culinary business at Karangmojo tourism area. They chosen as research subject by purposive sampling technique based on thinking that they are located in community that has been become laboratory of Nonformal Education Department, Yogyakarta State University.

Data collection used mix method namely interview, observation, and document analysis for gaining qualitative information and questioner used to reaching quantitative infomation of the research focus. These qualitative methods implemented using each guidline by researchers. To achieving data validity, questioner was developed according to literature review and then validated by experts whose give judgment to its improvement, while triangulation which is used to find realibilty of the qualitative data.

\section{RESEARCH FINDING}

The model development managed by phases includes: (a) need assesment of the capacity development, (b) the conceptual model development, (c) the model implementation, (d) and evaluation of the model development. Following description of each steps.

First, need assesment of the capacity development done by asking the target group to have discussion and giving them questioner on how networking activities have been done by themselves. The result show, as graph 1, that although the members of group see networking is important things (indicated by score 4), capacity to create network namely understanding of the networking mechanism, using internet and channel to gain business partners was still low (indicated by score no more 1). It could be seen that they have limitations to know potential actors who could be asked to joint or sinergize and share market that could be entered. So, the capacity must be increased in order to they are be professional.

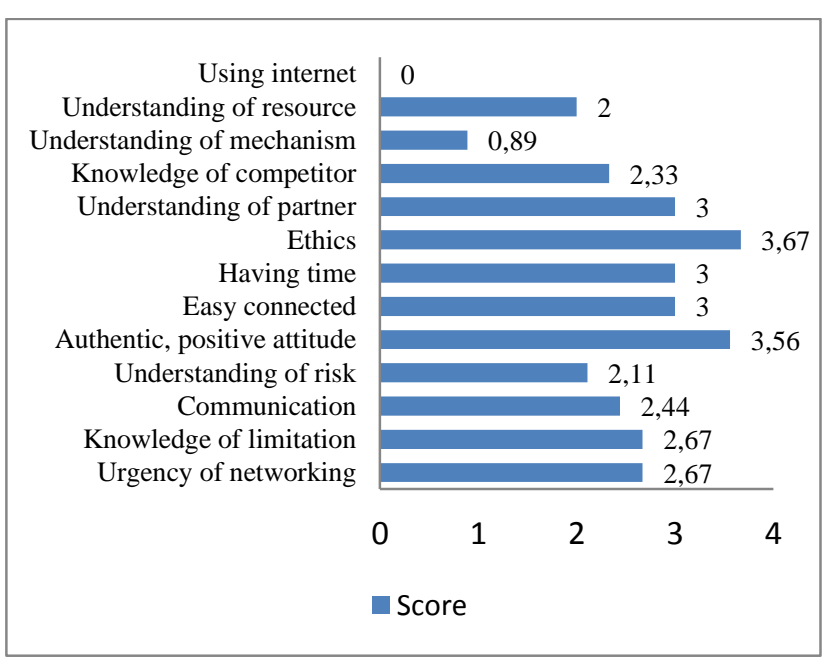

Fig 1. Performance of networking

Second, design conceptual model of the capacity development. Based on the identification, the conceptual model resulted as see in figure 1 . The model developed with focus on two teaching approachs which is chosen namely one is adult education approach that which participation of the target must be exist on planning, implementation, and evaluation of learning, and the others is experiential based learning that intended to give concrete and applicative curriculum. The both intended to give meaningful experiences to the targets, and more positioning them as individuals that have awareness and motivation to 
develope. And then, the model was consultated to development activities the model especially on experts in educational science for gaining validation of teaching design will be conducted. the model. Inputs from experts was used to complete

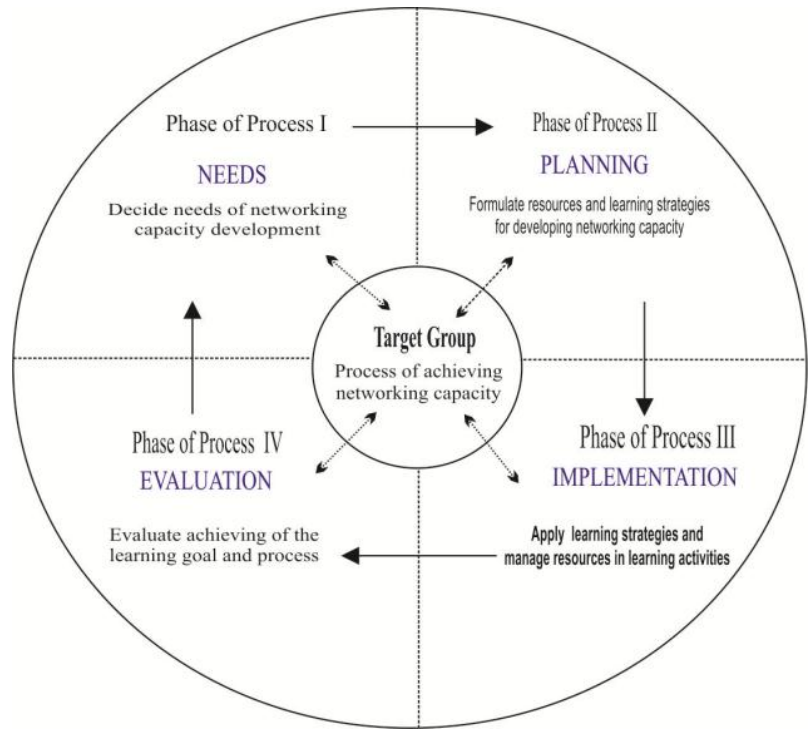

Fig 2. Model of Networking Capacity Development

Third, the model implementation. Refers to the of the model conducted through some steps as shown conceptual model resulted above, the implementation in table 1 bellows.

TABLE I. ACTIVITIES OF THE MODEL DEVELOPMENT

\begin{tabular}{|c|c|c|c|}
\hline FASE & Bentuk Kegiatan & Tujuan & Metode \\
\hline Need assesment & $\begin{array}{l}\text { Identified networking } \\
\text { capacity of the target }\end{array}$ & $\begin{array}{l}\text { Knowing level of the capacity } \\
\text { performance }\end{array}$ & Focused discussion \\
\hline Planning & $\begin{array}{l}\text { Rearrange activities of } \\
\text { development and supply } \\
\text { resources }\end{array}$ & $\begin{array}{l}\text { Preparing mechanism, resources, } \\
\text { and evaluation plan of the } \\
\text { development }\end{array}$ & $\begin{array}{l}\text { Coordination: with members } \\
\text { representatives, technical experts }\end{array}$ \\
\hline \multirow{7}{*}{ Implementation } & $\begin{array}{l}\text { Concisousenss, comittment, } \\
\text { building }\end{array}$ & $\begin{array}{l}\text { Rebuilding mutual comittment to } \\
\text { work/buisness }\end{array}$ & Group discussion \\
\hline & Enterpreneuship teaching & $\begin{array}{l}\text { Developing values, attitudes, and } \\
\text { knowledge of business }\end{array}$ & $\begin{array}{l}\text { Based experience discussion; } \\
\text { cooperative learning }\end{array}$ \\
\hline & Networking capacity learning & Creating networking capacity & Case study; Brainstorming \\
\hline & Vocational training & $\begin{array}{l}\text { Giving attitudes, knowledgem and } \\
\text { skills to do enterprise }\end{array}$ & $\begin{array}{l}\text { Practice of vacational skills from } \\
\text { practitioner of "peyek" production }\end{array}$ \\
\hline & & & business \\
\hline & Networking inforcement & $\begin{array}{l}\text { Building comittment, values, } \\
\text { attitudes, and skills to network }\end{array}$ & $\begin{array}{l}\text { Story telling of the groups successfull } \\
\text { Outbond conducted by Tosca Organizer } \\
\text { as fasilitator. } \\
\text { Reorganization of the group, creation } \\
\text { business group }\end{array}$ \\
\hline & $\begin{array}{l}\text { Practice of network } \\
\text { development }\end{array}$ & Giving Group tasks & $\begin{array}{l}\text { Practice grouply, practice of "peyek" } \\
\text { business }\end{array}$ \\
\hline Evaluation & Mutual evaluation & $\begin{array}{l}\text { Know the capacity competence of } \\
\text { the target }\end{array}$ & $\begin{array}{l}\text { Questioner } \\
\text { Reflection }\end{array}$ \\
\hline
\end{tabular}

Fourth, doing evaluation of the model shows output of the teaching by which information of development. For knowing success of the teaching activities done, evaluation conducted using questioner behavior change happened. It means that activity of and mutual reflection methods. Questionnaire given to each individuals at final of the teaching activities, and the capacity development for the target group of enterpreneurship education make them be able to have attitude, knowledge, and skills in creating of business so did mutual reflection among them about benefits networking. Each indicators of the capacity show that reached or felt by themselves on the model there was improvement. High or significant implementation that they have involved on it. Figure 2

performance happened to understanding of the 
networking mechanism that is indicated by score 0,89 change to score 3,56 .

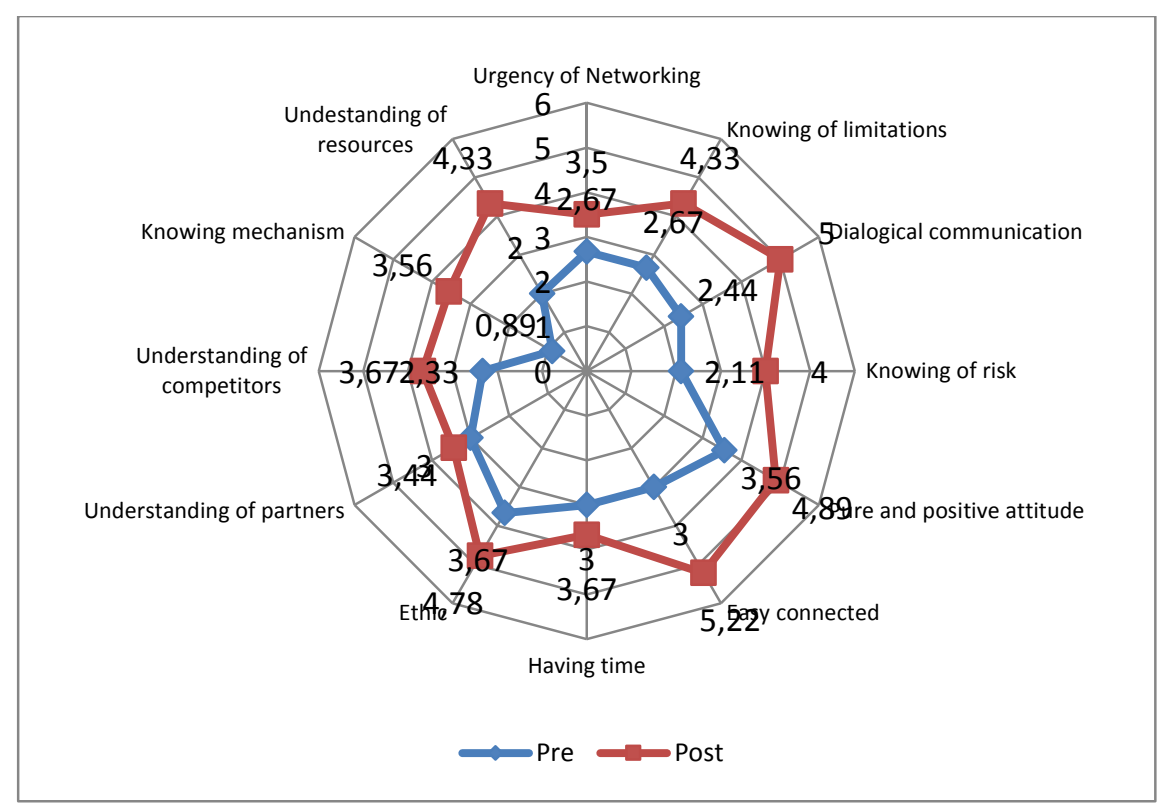

Fig 3. Output of the model development

Interviewe to the target group, facing question: “ whats kinds learning benefits you have after teaching on the capacity?" have informed that there are positive learning results. There are some behaviors which tends to meaninful namely they have high motivation to run business for success, self conciousness that enterpreneurship bussiness must be suppoted by shaping relation among actors both through friendship, family, and direct communication, desire to continue mutual business, good experiences of the product marketing of entreprise, and having skills of the "peyek" process production that is different to their skills of the process that they master in term of the taste, form, and packaging.

\section{DISCUSSION}

Success of the enterpreneurship activities are defineted by the actor competency. The competencies could be related to management, marketing, and even resources. One of these competencies urgent is networking capacity that is entite potentials to obtain resources through building network as work together with both internal and external sides. It could be directed to accomplishe resources such as employee, manager, and information system, and business processes for instance selling process, and business units of supply chain. On the entrepreneurhsip business, it could be done by focused on three aspects: one is focus on building of solidarity, work together, trust, and sharing of information among group members; second is related to relation creation positively between entrepreneurs and their partners in relevant or same business enviorenment where they are present for example relation with banking, investors, shops, universities, etc.; and third is relation between consumers of products or services individually or organizationally [26]. All of these needed to created and developed by them in order to success gained.

The model development conducted can give positive contribution to the target group. This is realized by obtainment significant output of the teaching which was seem from positive change of their behaviors in ways to master the networking capacities for running entreprise including: knowledge of the urgency of network, conciousness to have dialogical communication, attitude authenticly and positively, mechanism to gain partners, knowing of resources, ethical behavior, and easy connected, and avalibility of time to interact. Although these was not all be improve, there are more significant improvement of the aspects that is understanding of the networking creation. The success caused by teaching of the model implementation using experiential learning and adult education approach. Experiential based learning means that experiences which are possed individual, group or communitycould become tools and also content of educational process useful for learners who want to have or build any competency. On teaching process, experience will be understood, and then constructed, 
reorganized, adapted, reduced or obmited and even replaced by new one if it is viewed no more relevant [27]. Of course, experiences that have to be delivered on instructional process are educative and challenging [28].

Reflection on the entrepreneurship works have been occupated by the target group did by asking back of the success of business which has been run recently. The research result show that the target group have intention to advance again their enterprise that was viewed it has long vacum or has no merits economically. This supported by arround enviorenment that influences to their opinion. They belief in that it contains great chance for improving their wealth by through involve on activity of business at the tourism area. By this recflection, the target groups decided to reorganization mutual business groups that was based on agreement among them, comittment, and share vision and goal. Therefore, the target group members made new structure of management and have new process of production that is "peyek" production. This condition inform that internal networking development harmonious and functional must be conducted so that activities of entrepreneurhsip will be more affective and effecient.

Development of the entrepreneurial networking capacity will not be acheived easily, but it would find obstacles influences. One of these in the development process was frequency of the visitors of the Goa Pindul tourism which has descrease during the learning process happened. Its concequence, process of the peyek marketing to some shops of qulinary or traders at the area was not effective so that the target groups decided to stop this activity. It means that they confined development of the capacity - through product marketing. Assosiated with this, result of interview show that absence of personalia who was be sender or distributor to more potential outside districts of the Karangmojo was also become barrier. Ideally, networking activities in order to promote the business should be carried out by the perpetrators not only in environment arround of the tourism area but also to the environment is more heterogeneous or far outside of the environment. Therefore, experience-based learning process needs to be done is to provide a more challenging learning experience, accompanied by efforts to change the paradigm of the perpetrator and the internalization of entrepreneurial values. The process of enhancing network capacity needs to be done thoroughly, meaningfully, and involving the target group in real life.

\section{CONCLUSION}

Based on the results and dicussion above, it can be referred that model of the development of the enterpreneurial networking capacity to the target group in context of the community empowerment could improve their network of business, build their conciousness to run business well and enhance their skills to produce commodity. Therefore, it can be take some suggestions namely: the target group have to apply learning result that they achieved for improving their networking of business, manage mutual business activities and group efectively for gaining wealth, and create mutual learning opportunities that have benefits for business success; agents or providers of educational services need to teach soft skills compentecies to learners that support their activity, and design enterpreneurship education that is able to involve the learners, meaningful, challenging, and oriented to real life; and educational policy makers need to have plan and management of enterpreneurship education or empowerment integrated and blends any resources and other sides.

\section{ACKNOWLEDGMENT}

I thanks you very much to Director of The Research and Community Service Board, Ministry of the Research, Technology, and Higher Education who has facilitated on funding for conducting this research, to my collegues especially at Yogyakarta State University who have suggest and help me for completation my research, and to the committee of YICEMAP 2017 who have give chance for this publication.

\section{REFERENCE}

[1] Direktorat Pembinaan Kursus dan Pelatihan. Daftar Penerima Block Grant. [Online].; 2012 [cited 2015 Mei 2. Available from: http://www.inforkursus.net.

[2] Weslund, H. Social capital in the knowledge economy London: Springer; 2006.

[3] Suryono Y, et al. Community Entrepreneurship Education Jakarta: National Education and Culture Ministry; 2011.

[4] Tohani E. Implementation of the ADKAR Approach on Managing Life Skill Education in Yogyakarta. Jurnal 
Kependidikan. 2009 Mei; 39(1): p. 79-86.

[5] Azhar. Model of Entrepreneurhsip Learning at Community Learning Center in SKB Temanggung. Juurnal Kependidikan. 2011; 41(1): p. 11-12.

[6] Sumardiningsih S, Mulyaningsih E., \& Marzuki M. Model of The Creative Economic Education based Character as Bridging Course of Entrepreneurship Learning on The Entrepreneurship Subject. Jurnal Kependidikan. 2013 Mei; 43(1).

[7] Zu Z, Lin J, \&Lin D. Networking and Innovation in SMEs: Edivence from Guandong Province, China. Journal of Small Business and Enterprise Development. 2008; 15(4).

[8] Coleman, JS. Social Capital in The Creation of Human Capital. American Journal of Sociology. 1988; 94:S94-S120.

[9] Grooataert C \& Bastelaer TV. Introducation and Overview. In Bastelaer TV, editor. The Role of Social Capital in Development. Belbourne: Cambridge University Press; 2002b. p. 1-7.

[10] Todeva E. Business Networks: Strategy and structure. London: Routledge; 2006.

[11] Osterle, et al. The 8 strategy of networking development. www.forbes.com.

[12] Muijs D,Aincow M,Chaptan C, \& West M. Collaboration and Networking in Education New York: Springer; 2011.

[13] O`Donell A. The Nature of Networking in Small Business. Qualitative Market Research: An International Journal. 2004; $7(2)$.

[14] Catt H \& Scudamore P. The power of networking London: Kogan Page; 1999.

[15] Osterle, et al. The 8 Stragegy of Networking www.forbes.com. 2001: p. 90.

[16] Kramer E. 101 successful Networking Boston: Cource Technology, Cengage Learning; 2012.

[17] Catt H \& Scudamore O. The Power of Networking Boston: Kogan Page; 1999.

[18] Collison E \& Shaw E. Entrepreneurial Marketing: A Hostorical Perspective on Development and Practice. Management Decision. 2001; 39(2): p. 761-766.

[19] Strategic Direction. How Networking Can Help Small Business. Strategic Direction. 2011; 27(5): p. 15-17.

[20] de Klerk S. The Importance of Networking As A Management Skill. South African Journal of Business and Entreprise Development. 2010; 8(2): p. 174-184.
[21] Indrupati J \& Henari T. Entrepreneurial Success: Using Online Social Networking. Education, Business, and Society. 2012; 5(1): p. 47-62.

22. Rolland N \&Kamiska-Labbe R. Networking Inside The Organization: A Case Study on Knowledge Sharing. Journal of Business Strategy. 2010; 29(3): p. 5-11.

[23] Miller NJ,Besser TL, \& Weber SS. Networking as Marketing Strategy: A Case Study of Small Community Business. Qualitative Market Research: An International Journal. 2010; 13(3): p. 253-270.

[24] Preston J. A Continous Effort of Networking Sociability: Learning and Social Capital in Adult Life. In Schuller T,PJ,HC,BGA,\&BJ. The Benefit of Learning: The Impact of Education on Health, Family Life, and Social Capital. London: RoutledgerFalmer; 2004.

[25] Linehan M. Networking for Female Manager`s Career Development. Journal of Management Development. 2001; 20(10): p. 823-829.

[26] Weslund H. Social Capital in The Knowledge Economy London: Springer; 2006.

[27] Illeris K. Contemporary Theories of Learning New York: Taylor \& Prancis Routledge; 2009.

[28] Dewey J. Democracy and Education New Delhi: Aakar Books; 2004. 